\title{
Chapter 2 \\ Rights of and Over Animals in the ius \\ naturae et gentium (Sixteenth \\ and Seventeenth Centuries)
}

\section{Annabel Brett}

\begin{abstract}
The chapter examines different theological and philosophical paradigms of rights in the early modern period. It shows that, contrary to initial appearances, animals were not totally excluded from any kind of right, and that violence against them was not always regarded as legitimate. Remarkably, one of the founders of the discipline of the law of nature and law of nations (ius naturae et gentium), Samuel Pufendorf (1632-1694), acknowledged animal pain-although he did not translate this acknowledgment into a moral wrong of doing violence to animals, or grant animals moral rights.
\end{abstract}

De jure naturae et gentium, 'The law of nature and of nations', is the title of Samuel Pufendorf's eight-volume masterpiece of philosophical jurisprudence, first published in 1672. It provides the tag by which an entire discourse is known, one that dominated legal philosophy at European universities for over two hundred years. Pufendorf's Protestant articulation of its principles was pivotal both for transmitting it to the Eighteenth Century and for giving it a history, which in his eyes began with his fellow-Protestant Hugo Grotius. In fact, however, its roots stretch back to the early Sixteenth Century, to the lawyers whom Philip Melanchthon gathered around him at Wittenberg and (more importantly for the future structure of the discourse) to the Catholic scholastic theologians who were originally based at Salamanca in Spain but subsequently spread out over the whole of CounterReformation Europe. In the confessional conflict that would burn throughout the

Revised version of the original published article "Rights of and over Animals in the Ius Naturae et Gentium (Sixteenth and Seventeenth Centuries)“ by Annabel Brett, American Journal of International Law Unbound, Volume 111, 2017, pp. 257-261. The original article was published as an Open Access article, distributed under the terms of the Creative Commons Attribution licence (http://creativecommons.org/licenses/by/4.0/).

\footnotetext{
A. Brett $(\square)$

University of Cambridge, Faculty of History, Cambridge, UK

e-mail: asb21@cam.ac.uk

(C) The Author(s) 2020

A. Peters (ed.), Studies in Global Animal Law, Beiträge zum ausländischen öffentlichen Recht und Völkerrecht 290, https://doi.org/10.1007/978-3-662-60756-5_2
} 
Sixteenth and Seventeenth centuries, theologians on all sides used law to define the space of the political, and used the idea of natural law to underpin that space, even while shaping it differently according to their divergent narratives of sin and redemption. While the ius naturae et gentium was an academic genre, therefore, its content was not. It was a theory and a legitimation of the state, and the arc of its reasoning from nature to the nations ran through the institution of political power. The state and its power are constructed not so much upon right (ius) per se, but on the potential for the violation of right (iniuria), and the demand for such violation to be vindicated, by law or ultimately by war. At its very barest-although this is to traduce the richness and complexity of the discourse- the ius naturae et gentium is a theory of legitimate violence. When it comes to animals, what we find is that they are systematically excluded from the potential to suffer violation of right and therefore from political space and political justice. As we shall see, however, this did not always mean that they were totally excluded from any kind of right or that every act violence against them was always legitimate.

The ius naturae et gentium was premised upon an idea of human nature. In the period with which we are concerned, very few doubted - and if they did, it was often (although not always) for the sake of deliberate paradox - that there was such a thing as distinctively human nature, and that this distinction consisted in the natural possession of the capacity to reason. Such conviction was the combined heritage of Christian theology and of (most) classical philosophy, as well as scattered pronouncements in the civil and canon laws. The important point for our purposes is that this heritage prompted scholars in all these three inter-connected disciplines to think through human nature in relation to animal nature. Thus, Scripture in the Book of Genesis directly connected man's nature as the image of God with the dominium that God gave man over animals. ${ }^{1}$ Aristotelian philosophy (the dominant philosophy of the universities) conceived the faculty of reason as something that human beings possess on top of a whole range of capacities and associated actions that humans have in common with animals. In civil law, the Roman jurist Ulpian likewise posited a natural ius that is common (commune) to both humans and other animals; he mentioned as belonging to it the union of male and female, which human beings call marriage, and the procreation and rearing of children. ${ }^{2}$ For their different reasons, theologians, philosophers and lawyers were almost universally reluctant to deny that the natural capacities and behaviours of animals had any normative force whatsoever. The question was how to square that reluctance with their shared insistence that no animal could make any political claim on any human being.

The Catholic scholastics built their understanding of natural law upon the account offered by the Thirteenth-Century theologian Thomas Aquinas in his Summa theologiae. For Aquinas, all law is the work of reason, and natural law is the participation of human reason in God's eternal law. The characteristic of reason is the ability to conceive a good, which is accompanied by the ability to choose a good

\footnotetext{
${ }^{1}$ Genesis I. 26.

${ }^{2}$ Mommsen/Krueger/Watson, The Digest of Justinian 1985, Vol. 1, Book I, 1.1.3.
} 
and to act purposively to attain that good. The capacity for such action-free-will, in short-is characterised as dominium over one's own actions, and only human beings among all terrestrial creatures have it. It is this self-dominium that grounds the original dominium that God gave man over the other creatures in Genesis I. 26. According to Aquinas, this original dominium was granted for the sake of use, by which he mean the purposive ordering of a thing towards a chosen good, for example of food to stay alive. Later scholastics accepted his argument that animals are incapable of use just as they are incapable of dominium, because both demand purpose and purpose depends upon rationality. Given that, increasingly, scholastic philosophers of the period conceived a broad equivalence between dominium and right (ius), the logical consequence of this line of reasoning was to push animals out of the sphere of rights entirely: to make them purely used rather than users, incapable of suffering any violation of right and therefore entirely outside any relations of justice. There would therefore appear to be no limit upon the violence that could legitimately be done to them. An extreme example was the Jesuit Luis de Molina (1535-1600) remarking that animals are incapable of suffering iniuria and that therefore no more wrong is done to an animal in killing it than in snapping a twig off a tree. ${ }^{3}$

However, other scholastics were uneasy with the proposition that natural animal lives, equally created by God, had no normative value at all. The agreed exclusion of animals from the phenomenon of dominium did not mean, for all scholastics, that animals had no rights at all. Some were prepared to keep ius separate from dominium, at least to some extent, and thereby to see animals as possessing rights in a different sense: not rights over things, but rights to the activities and goods required for the flourishing of their particular nature. Again this stemmed ultimately from Aquinas, who excluded animals from rational participation in eternal law but allowed them an instinctual participation insofar as they instinctively pursue those things that are good for them. Moreover, a range of the goods that humans are commanded to pursue by natural law are also shared with animals, for example the basic good of self-preservation. The Dominican Domingo de Soto (1485-1650) accordingly allowed 'all things' a natural right to pursue their self-preservation. ${ }^{4}$ This might have no implications at all for the rightfulness of human treatment of animals: it might simply mean that animals were behaving in a naturally rightful manner in running away, for example, but not that any wrong was done to them in capturing them. The Jesuit Juan de Salas (1553-1612), however, argued for such rights within an Aristotelian teleology wherein plants are made for animals and animals made for man:

one should concede to animals - yes, and even to inanimates - right in the sense of what is rightful, or a kind of faculty of doing something, the use of which it would be an injustice to interfere with. For they demand, as if by their own proper right, the things that are naturally

\footnotetext{
${ }^{3}$ de Molina, De iustitia et iure 1614. See also Brett, 'Is there any place for environmental thinking in early modern European political thought?' 2018, 23-42.

${ }^{4}$ de Soto, De iustitia et iure 1967-1968, Lib. IV, q. 2, a. 2; Lib IV, q. 7, a. 1.
} 
due and proportioned to them, so that they may exist in a good state, and be preserved, and serve the uses of men for whose conveniences they were brought forth. ${ }^{5}$

In this conception, then, justice and rights can exist within a user-used relationship; indeed, it is precisely this God-given relationship, at least in part, which argues for the right. There is thus some limit on human behaviour towards animals, despite the fact that Salas still refused animals any dominium and any capacity to suffer iniuria in the strict sense.

If we turn now to Protestant natural jurisprudence, we find the topic of animal rights inflected by the different way in which they conceive of natural law. Instead of the focus on individual agency that characterises the Catholic understanding, natural law in the Protestant tradition centrally regulates human relations with others. The ius naturae is accordingly the law of natural society. Joining hands with humanist civil jurisprudence in this respect, the Protestant tradition sees ius as an interpersonal phenomenon, a relational quality that only exists where there is society or community. It demands the kind of other-regarding behaviour (what would later be termed sociability) that only human beings, as rational creatures, are capable of. Thus the society argument would seem to exclude animals just as surely as the dominium argument, and the majority of humanist and Protestant jurists regarded any idea of a ius naturale common to human beings and animals as, quite simply, a mistake. ${ }^{6}$ Some, indeed, were more sympathetic to the idea that animal agency could be lawful, or that we could talk of right in respect of them. Thus the French humanist lawyer Jacques Cujas (1522-1590) held that animals have been taught ius naturale, and follow it equally as do humans, in such things as rearing their young. But all the same, he explicitly ruled out any 'community of right' between animals and humans: there is no shared juridical space, and thus no space for justice or injustice, between them. ${ }^{7}$

In a deliberately controversial early essay on ius naturale, gentium et civile published in 1584, Alberico Gentili, Regius Professor of Civil Law at Oxford, countered the humanist argument from community by suggesting that natural right - as opposed to right under the law of nations, or under civil law-is possessed by both human beings and animals independently of any community, in the natural activities of their own daily lives: walking, sleeping, running, eating. ${ }^{8} \mathrm{He}$ recognised, however, that the key question was not simply possession of right, but the potential for its violation (iniuria). To the argument that animals do not have rights because they are not capable of violation of right, Gentili responded that there are two kinds of iniuria. The first, and central, sense, is that of a deliberate violation, which requires a mind (animus); Gentili characterised it as a kind of contumely or contempt. But in a second sense, we can say that everything that happens without

\footnotetext{
${ }^{5}$ de Salas, Tractatus de legibus 1611, tract. 13, disp. 2, sect. 2, fo. 35 .

${ }^{6}$ The best discussion of the debate is in Scattola, Naturrecht 1999, 161-78.

${ }^{7}$ Scattola, Naturrecht 1999, 168-69.

${ }^{8}$ Gentili, Epistolarum ac lectionum libri IV 1583-4, Lib. III, cap. 1 De jure naturali, gentium, \& civili, 342-43 [recte 144-5].
} 
right, sine iure, also happens by iniuria as a kind of unright or nonright, and animals as well as humans are capable of this. The first can only be committed by humans. By contrast, animals, which lack animus, can only violate each other's rights (and presumably the rights of human beings too) in the second way. Gentili did not directly say, in this work, whether humans can contumeliously violate animal rights. However, in his later work On the Law of War (1598), Gentili addressed the treatment of captives in war and directly paralleled the treatment of slaves and animals, both equally without any rights against their captors either under civil law or under the law of nations. The implication is that they are both confined to the sphere of natural right in the same way, but that nevertheless both have some juridical claim against their captors. His initial point was one about kindness rather than justice, and his example is the Athenians who allowed their animals rest, pasture and even burial after 'the long labours of life'. The argument takes a more legal turn, however, when he invoked 'the law of God', i.e. Deuteronomy: 'Thou shalt not muzzle a threshing ox ${ }^{9}{ }^{9}$ If this is not strict iniuria, it is nevertheless some kind of affront to justice in a broader sense, a sense that includes both human beings and animals.

Two towering figures of the Protestant Seventeenth Century followed Gentili in positing animal rights, but without the consequences for human treatment of them that Gentili drew. In his early work De iure praedae, Hugo Grotius (1583-1645) recognised a right (or at least the rightfulness) of self-preservation in all animals, human or otherwise. However, he placed this right of pursuing one's own good explicitly prior to any recognition of the other's good, and thus prior to any justice properly so-called and to the natural society that depends upon it. For Grotius, this requires reason, which animals do not possess. He did accord them a glimmering of regard for others, for example in the way that they care for their young, but held that this faint sense is not enough for justice or for natural society. ${ }^{10}$ Animal rights are therefore outside the sphere of justice; they place no constraints on the rights of human beings. Equally, Thomas Hobbes, at least in De cive (1642), placed animals and humans in the same natural juridical space when he said that a man will kill an animal with the same right that an animal kills a man. ${ }^{11}$ But this space is the 'condition of nature', which Hobbes famously equated with a condition of war, in which again there is no justice, or at least no justice in effect. ${ }^{12}$ No one-no human being, no animal — can be convicted of violating another's right in the condition of nature. Human beings can escape this terrible situation by covenanting to create a civil state, but animals remain forever in the condition of nature. They can never have any right not to be killed or otherwise used for any purpose, albeit neither can they ever be obliged not to kill human beings.

\footnotetext{
${ }^{9}$ Gentili, De jure belli libri tres 1933, Vol. II: Translation, Bk III, Ch. 9.

${ }^{10}$ Grotius, Commentary on the law of prize and booty 2006, 21-28.

${ }^{11}$ Hobbes, De cive 1998.

${ }^{12}$ Hobbes, Leviathan 1996, Ch. 13.
} 
Despite their differences, Gentili, Grotius and Hobbes were all in these works indebted to a distinct strand within late renaissance philosophy which deliberately denied, or even inverted, the traditional theory of the natural superiority of human beings over animals based on the supposedly natural and exclusive human possession of reason. ${ }^{13}$ In its neo-Epicurean mode, shared by the early Grotius and Hobbes, this served to place human beings and animals equally in a naturally lawless condition. But in another version-drawing on other strands of Hellenistic philosophy, such as skepticism, ancient vegetarianism, and the Stoic repugnance towards anger and cruelty and other destructive passions - the emphasis was rather on the positive qualities that animals shared with human beings. Gentili referred to some of this material to confirm his thesis that animals were included in the ius naturale. ${ }^{14}$ Ideas of the reason and virtue of animals were powerfully articulated by writers like Michel de Montaigne, especially in the Apology for Raymond Sebond, and Montaigne's follower Pierre Charron, whose works enjoyed huge success all over Europe. ${ }^{15}$ Although the strategy of inversion was primarily deployed as an invitation to moral reflection and inner freedom, this style of philosophy was also marked by its insistence on the concrete practice of our lives and our behavior towards other beings. It left a deep impression upon Samuel Pufendorf, who engaged both approvingly and disapprovingly with Charron's De la sagesse throughout the first books of De jure naturae et gentium.

Pufendorf's legal philosophy rested upon a distinction, inherited ultimately from Jesuit scholastics such as Francisco Suárez, between 'natural entities' and 'moral entities'. While the former are the result of natural processes, the latter are 'imposed' by the free will of a rational agent: God, in the first instance, and human beings thereafter. The created 'moral' world, which includes persons, rights, obligations, statuses, powers, and all values, excludes animals, since for Pufendorf its condition, rationality, was an exclusively human characteristic, 'whatever Charron... has maintained to the contrary'. ${ }^{16} \mathrm{He}$ stressed that moral entities distinguish all that is decorous and civilised in the life of human beings from the brute life of animals, underpinning the point with a complex psychological account of the working of such moral entities upon human passions and actions. The direct corollary of this position, however, was that the superiority of human life was not a function of reason alone. This was his debt to Charron and to Hobbes. Without moral entities, reason was a mere cunning; morality is 'imposed', not natural. ${ }^{17}$ But while Pufendorf endorsed some of the positive evaluation of animal lives as lacking the vices that characterize

\footnotetext{
${ }^{13}$ See the contribution of Anna Becker, chapter 3, in this volume.

${ }^{14}$ Gentili, Epistolarum ac lectionum libri IV 1583-4, Lib. III, cap. 1 De jure naturali, gentium, \& civili, 346-47.

${ }^{15}$ de Montaigne, An apology for Raymond Sebond 1987; Charron, De la sagesse 1986. Two translations of the latter work into English were made at the beginning and end of the seventeenth century, by Samson Lennard and George Stanhope.

${ }^{16}$ Pufendorf, De jure naturae et gentium libri octo 1934, Vol. II: Translation, Book I, Ch. 3, n. 1. The reference is to Book I, Ch. 34 of De la sagesse.

${ }^{17}$ Pufendorf, De jure naturae et gentium 1934, Book II, Ch. 1-2; Book I. Ch. 6.
} 
human beings, the same theory of moral entities meant that such lives had no moral quality, nor did animals have any moral right to live them. God did not impose any natural law on both humans and animals; what they had in common was certain regular natural behaviours, like rearing young, but the fact that God had created these regularities did not make them law, and any natural goodness inherent in them was not sufficient for moral status. ${ }^{18}$

When it came to natural human rights over animals, Pufendorf, like Montaigne, rejected as a piece of human vanity the view that the only reason for other creatures' existence was to serve human beings. Nevertheless, he argued that God had created man with needs which could not be met without using animals, a use which therefore must have been morally licensed by God and which by the same token could not involve the violation of right (iniuria). ${ }^{19}$ But he then paused over the question whether that use legitimately extended to slaughtering them. After all, humans could use animals for food in other ways, for example by milking them; they did not have to eat them. The crucial point is that, unlike plants, animals suffer agony (cruciatus) in being killed. Pufendorf here rehearsed at striking length all the late renaissance philosophical arguments against doing violence to animals. His response was curiously indirect. He approved temperance and frugality in eating. But from the assertion that God had imposed no law in common between human beings and animals, and thus no command to cultivate mutual society, Pufendorf drew the conclusion that there was a state of war between them, and thus that neither side could commit iniuria on the other. Therefore, human beings do not commit iniuria on animals when they kill them, either for food or for any other reason such as keeping the population down. He ended with a caution, however, against abuse of animals as an abuse of God's creation.

In his popular abridgement of De jure naturae et gentium, entitled De officio hominis et civis, Pufendorf kept only the first of the above arguments. Remarkably, however, he also kept the mention of animal pain: '(...) harmless animals which it is not wrong for men to kill and consume, even though they die in pain (dolore). ${ }^{20}$ As we have seen, Pufendorf's whole system depends on separating out a natural evil, like pain, from moral wrong. And yet his mention of it ruptures the smooth flow of legitimation. In allowing animal pain to break the surface of his text, Pufendorf preserved some of the late renaissance attack on human complacency even while he denied that it translated into animal rights against humans. In terms of the preceding ius naturae et gentium, this acknowledgement of pain is (to the best of my knowledge) unique.

\footnotetext{
${ }^{18}$ Pufendorf, De jure naturae et gentium 1934, Book II, Ch. 3; Book I, Ch. 2.

${ }^{19}$ Pufendorf, De jure naturae et gentium 1934, Book IV, Ch. 3.

${ }^{20}$ Pufendorf, On the duty of man and citizen 1991, Book I, Ch. 12.
} 


\section{References}

Brett, A. (2018). Is there any place for environmental thinking in early modern European political thought? In K. Forrester \& S. Smith (Eds.), Nature, action and the future. Political thought and the environment (pp. 23-42). Cambridge: CUP.

Charron, P. (1986). De la sagesse. Paris: Fayard.

de Molina, L. De iustitia et iure Tract. II, disp. 3, n. 6 (ed. Mainz 1614).

de Montaigne, M. (1987). An apology for Raymond Sebond, (Michael Andrew Screech, Trans.). (Eds.), Harmondsworth: Penguin.

de Salas, J. (1611) Tractatus de legibus. Barcelona.

de Soto, D., De iustitia et iure (facs. ed. Salamanca 1556 with parallel Spanish translation, Madrid: Sección Teólogos Juristas, Instituto de Estudios Políticos 1967-1968).

Gentili, A., Epistolarum ac lectionum libri IV (London 1583-1584).

Gentili, A. (1933). De jure belli libri tres (Vol. 2). Oxford: Clarendon Press.

Grotius, H. (2006). Commentary on the law of prize and booty (Gwladys L. Williams, Trans.). Martine Julia van Ittersum (Eds.), Indianapolis: Liberty Fund

Hobbes, T. (1998). De cive (Richard Tuck and Michael Silverthorne, Trans.). (Eds.), Cambridge: CUP.

Hobbes, T. (1996). In R. Tuck (Ed.), Leviathan. Cambridge, CUP.

Mommsen, T., Krueger, P., \& Watson, A. (Eds.). (1985). The Digest of Justinian (Vol. 4). Philadelphia PA: University of Pennsylvania Press.

Pufendorf, S. (1991). On the duty of man and citizen (James Tully, Trans.). Michael Silverthorne (Ed.), Cambridge: Cambridge University Press.

Pufendorf, S. (1934). De jure naturae et gentium libri octo (Vol. 2). Oxford: Clarendon Press.

Scattola, M. (1999). Das Naturrecht vor dem Naturrecht. Zur Geschichte des "ius naturae" im 16. Jahrhundert. Tübingen: Niemeyer.

Annabel Brett is Professor of Political Thought and History at the University of Cambridge. She is the author of Liberty, right and nature. Individual rights in later scholastic thought (1997) and Changes of state. Nature and the limits of the city in early modern natural law (2011), as well as of a number of articles on the history of natural law, human rights and international law. A major recent theme of her research is the way in which geographical space and non-human nature have historically been conceived in relation to human beings and political formations, and how those issues are theorised in contemporary political thought.

Open Access This chapter is licensed under the terms of the Creative Commons Attribution 4.0 International License (http://creativecommons.org/licenses/by/4.0/), which permits use, sharing, adaptation, distribution and reproduction in any medium or format, as long as you give appropriate credit to the original author(s) and the source, provide a link to the Creative Commons licence and indicate if changes were made.

The images or other third party material in this chapter are included in the chapter's Creative Commons licence, unless indicated otherwise in a credit line to the material. If material is not included in the chapter's Creative Commons licence and your intended use is not permitted by statutory regulation or exceeds the permitted use, you will need to obtain permission directly from the copyright holder.

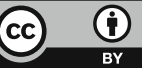

